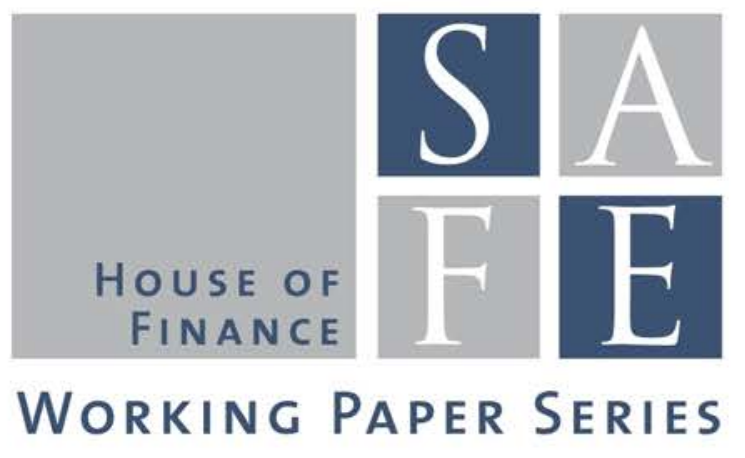

Alfons J. Weichenrieder - Fangying Xu

\title{
Are Tax Havens Good? Implications of the Crackdown on Secrecy
}

SAFE Working Paper No. 111

SAFE I Sustainable Architecture for Finance in Europe A cooperation of the Center for Financial Studies and Goethe University Frankfurt 


\section{Non-Technical Summary}

The financial crisis and the budgetary problems it implies for many governments have led to an intensified search for additional tax revenues. Among other things, the crisis triggered a strong interest in the activities of tax havens. Partly, this might be motivated by tax havens' hosting of unregulated shadow banking. To a large extent, however, the revived interest in the activities of tax havens came from the fear of losing valuable tax revenues. This triggered the G20 leaders in the midst of the crisis in 2009 to propose to "take action against non-cooperative jurisdictions, including tax havens".

The essential OECD strategy, much intensified since 2008, was to greylist alleged tax haven jurisdictions and to delist jurisdictions that agree on a standard of information exchange and sign at least twelve bilateral tax information exchange agreements (TIEAs). Since 2009, this initiative has led to an exploding number of TIEAs that already exceeds 800 (OECD, 2013).

If effective, tax information exchange eliminates one of the two important features of a tax haven: while the treaties do not change the low or zero taxation of income charged by tax havens, they may eliminate the shelter that secrecy offers for tax evaders and tax avoiders. This secrecy may particularly matter for investments in India and China. While in India the largest share of documented FDI stocks comes from Mauritius, the British Virgin Islands is listed (after Hong Kong) as the most dominating origin of FDI stocks in China. For both India and China, large parts of these FDI stocks may result from round-tripping: Chinese or Indian investors are using foreign tax havens to pretend that their investments are foreign owned, which may result in lower tax rates and other benefits.

The present paper evaluates some of the potential consequences that the current crackdown on tax-haven secrecy may have. In particular, we comment on the recent view that tax haven countries may have a positive role for other countries as they help high-tax countries to differentiate their tax rates for different mobile firms. Instead, the present paper suggests that for some countries rather the opposite is plausible: tax-haven secrecy makes it harder to tell apart the owners of foreign firms from domestic investors and thus has a negative impact on non-haven countries' welfare. Consequently, a crackdown on secrecy should therefore be beneficial for hightax countries. 


\title{
Are Tax Havens Good? Implications of the Crackdown on Secrecy*
}

\author{
Alfons J. Weichenrieder ${ }^{\dagger}$ and Fangying $\mathrm{Xu}^{\ddagger}$
}

July 2015

\begin{abstract}
The pressure on tax haven countries to engage in tax information exchange shows first effects on capital markets. Empirical research suggests that investors do react to information exchange and partially withdraw from previous secrecy jurisdictions that open up to information exchange. While some of the economic literature emphasizes possible positive effects of tax havens, the present paper argues that proponents of positive effects may have started from questionable premises, in particular when it comes to the effects that tax havens have for emerging markets like China and India.

Keywords: Tax haven, secrecy, tax information exchange, China, India

JEL: H2, H7
\end{abstract}

\section{The Current Crackdown on Tax Havens}

The financial crisis and the budgetary problems it implies for many governments have led to an intensified search for additional tax revenues. Among other things, the crisis triggered a strong interest in the activities of tax havens. Partly, this may have been motivated by tax havens' hosting of unregulated shadow banking. To a large extent, however, the revived interest in the activities of tax havens came from the fear of losing valuable tax revenues. This triggered the G20 leaders in the midst of the crisis in 2009 to propose to "take action against non-cooperative jurisdictions, including tax havens. We stand ready to deploy sanctions to protect our public finances and financial systems". ${ }^{1}$

The term "tax haven" is used in different ways by different authors, but usually the term refers to jurisdictions that impose no, or hardly any income taxes on foreign investors. In addition, typical tax haven jurisdictions are reluctant

${ }^{*}$ This paper is part of the research program of the Center "Sustainable Architecture for Finance in Europe" (S A F E), funded by the State of Hessen initiative for research LOEWE.

${ }^{\dagger}$ Corresponding author: Goethe University Frankfurt, Vienna University of Business and Economics, and CESifo, aw@em.uni-frankfurt.de.

$\ddagger$ Goethe University Frankfurt.

${ }^{1}$ See OECD (2010). 
to reveal tax relevant information about the income that foreign investors earn in the respective tax haven. There are different lists of typical tax haven jurisdictions. Usually, small jurisdictions, like Andorra, the Bahamas, Barbados, Bermuda, the British Virgin Islands, the Cayman Islands, the British Channel Islands, the Netherlands Antilles, or Panama, are prominent entries on these lists. Somewhat larger countries such as Switzerland and Austria have been qualified as well according to some lists. See Hebous (2014) for an overview.

Tax haven jurisdictions have been under pressure from various angles. Some have criticized lack of financial regulations in these countries. More relevant for our discussion is a prominent attack which came from an initiative by the Organisation for Economic Co-operation and Development (OECD). The essential strategy, much intensified since 2008, was to greylist alleged tax haven jurisdictions and to delist jurisdictions that agree on a standard of information exchange and sign at least twelve bilateral tax information exchange agreements (TIEAs). Since 2009, this initiative has led to an exploding number of TIEAs that already exceeds 800 (OECD, 2013). ${ }^{2}$

The signing of a TIEA implies that a country can contact the tax authorities of a partner country and ask for tax relevant information. Information must not be denied just because the relevant information is not tax relevant in the addressed country or because the tax payer's behavior that is the request reason is not an offense in this country. On the other hand, a TIEA does not allow for "fishing expeditions" in which information on a large number of tax payers is requested without giving individual reasons for the request.

If effective, tax information exchange eliminates one of the two important features of a tax haven: while the treaties do not eliminate the low or zero taxation of income, they may eliminate the shelter that secrecy offers for tax evaders and tax avoiders.

A tax avoider seeks to reduce the tax burden by employing legally permitted instruments, while a tax evader is in breach with existing tax law and may have an even larger demand for secrecy. Yet, even a tax avoider may have a preference for secrecy as the knowledge about tax loopholes may foster new tax legislation to close the loophole.

The present paper evaluates some of the potential consequences that the current crackdown on tax-haven secrecy may have. In particular, we comment on the recent view that tax haven countries may have a positive role for other countries as they help high-tax countries differentiate their tax rates for different mobile firms. Instead, the present paper suggests that for some countries rather the opposite is plausible: tax-haven secrecy makes it harder to differentiate between domestic and foreign firms and therefore has a negative impact on nonhaven countries' welfare. Consequently, a crackdown on secrecy should therefore be beneficial for these countries.

The rest of the paper is organized as follows. Section 2 briefly describes the

\footnotetext{
${ }^{2}$ It has been pointed out that one strategy of tax havens to keep their secrecy status could have been to sign TIEAs primarily with other tax havens and countries of little economic importance. Bilicka and Fuest (2014) show that this was not the case: in general, TIEAs were formed between countries that have economic ties and sizable bilateral investment.
} 
different (shady) services that tax havens sometimes offer for investors. Section 3 reviews recent papers on the impact of tax havens on other countries' welfare. Section 4 highlights the stunning importance of tax havens as conduit countries for investments into China and India. It also comments on the possibility of round-tripping investments that may be included in these figures. A round-tripping investment applies when the country of the ultimate owner of the investment and the host country are identical, but the use of a conduit country camouflages the investment as a foreign direct investment (FDI). Section 5 then offers a revised version of the model by Hong and Smart (2010), [HS (2010) in the following] and introduces round-tripping investment in a stylized way. Section 6 concludes.

\section{Services Offered by Tax Havens to Investors}

Some of the advantages that tax haven jurisdictions offer to investors and tax payers do not necessarily rely on secrecy. Several well-known tax avoidance techniques by multinational enterprises (MNEs) simply take advantage of permanently low tax rates. ${ }^{3}$ There is ample empirical evidence on this in the literature. MNEs may allocate liquid assets like patents (Karkinsky and Riedel, 2012) or financial assets (Ruf and Weichenrieder, 2012) to subsidiaries in low tax jurisdictions to reduce income taxes on the returns of these assets. Closely related, MNEs may try to optimize by borrowing in high-tax countries, while shifting equity and lending to high-tax subsidiaries into tax havens with zero, or nearly zero corporate income taxes (Schindler and Schjelderup, 2012). MNEs may also try to use adjustment of transfer prices on intra-firm trade to shift profits to tax havens and low-tax jurisdictions more generally (Weichenrieder, 2009).

MNEs, however, may nevertheless benefit from secrecy. Even if tax avoidance schemes are legal under current legislation, publicity may still be disruptive as it may trigger new anti-avoidance legislation. For this and other reasons, tax haven affiliates may be used to obscure the intentions behind tax haven activities. Hebous (2014) suggests that German-owned subsidiaries in tax havens are suspiciously often held indirectly via other intermediate affiliates. The creation of such ownership chains may be explained by the desire to obscure tax haven activities.

It has also been argued that secrecy may allow businesses to avoid liability for environmental damages and other misconduct by obscuring ownership (Schjelderup, 2011). For example, individuals and firms specializing in telephone fraud or internet scams use tax haven operations to collect their booty and to avoid the risk of reclaims. Sometimes tax and non-tax offenses may go hand in hand. Sherman (2010) argues that offshore shell companies are often used to obscure the bribes in the arms industry. Gordon (2009) describes how

\footnotetext{
${ }^{3}$ Low tax rates would be largely ineffective without the high political stability and good governance that tax havens usually offer. The requirement of political stability means that not all small jurisdictions can act as a successful tax haven (Dharmapala and Hines, 2009).
} 
resource extracting firms bribe government officials by using tax haven operations. Together with such evidences empirical study also shows German parent companies that are invested in high corruption countries have a higher probability to own a tax haven operation than parents operating in a low-corruption environment (Hebous and Lipatov, 2013).

Empirical studies that look at the effects of tax information exchange on the location choice of MNEs are still in their infancy. However, there is an emerging of empirical evidences that secrecy matters not only for private portfolio flows but also for foreign direct investments. Blonigen, Oldensky and Sly (2014) look at U.S. tax treaties and find that bilateral FDI in R\&D intensive industries may suffer compared to other industries if a tax treaty is introduced. The authors interpret this as an evidence of that transfer pricing strategies of multinationals, which should be more important in R\&D intensive sectors, may be thwarted by information exchange that may be introduced by bilateral tax treaties. Braun and Weichenrieder (2015) consider Germany's new bilateral TIEAs and find that, compared to a group of tax haven countries which did not strike an agreement with Germany, tax haven countries that entered into an agreement received less German investments over time. These studies suggest that secrecy does matter for FDI, which may help to explain why previous empirical studies have found it difficult to show a positive effect of bilateral tax treaties on FDI (Bloningen and Davies, 2004). To the extent that these treaties improve information exchange, the positive effect due to lower withholding rates and the elimination of double taxation may still be (partly) undone.

Of course, tax haven services are not only directed towards MNEs. Allegedly on a more important scale, tax havens in the past may have helped private individuals to hide their assets and income from their domestic tax authorities. High profile cases where private individuals have invested large sums in tax havens exist in many countries. For obvious reasons, secrecy is of essential importance for this type of investors and, if at all, TIEAs should have an effect on assets allocation for them.

Johannesen and Zucman (2014) have recently looked at the available empirical evidences. Their analysis shows that agreements on the exchange of information led to a significant shift in non-bank deposits (i.e. deposits that are owned by non-banks) suggesting that tax evaders either move their deposits to tax havens that have no treaty with their respective home country or at least show a preference for non-cooperative jurisdictions when it comes to new investments. Hanlon, Maydew and Thornock (2015) find evidence that US TIEAs have reduced the use of respective tax havens by American portfolio investors.

\section{Services Offered to Other Countries}

For readers that are non-native in the literature on tax havens it may come as a surprise that a sizable academic literature is discussing possible positive effects 
of tax havens on other countries. One claim that has been made (Hines, 2010) is that other countries profit from nearby tax haven jurisdictions in terms of higher economic growth. A possible transmission channel could be that investments in tax havens allow firms to reduce their costs of capital when engaging in hightax countries (Desai, Foley and Hines, 2006a). ${ }^{4}$ While Desai, Foley and Hines (2006b) find that the demand for tax haven operations by U.S. MNEs increases if a MNE operates in a high tax environment, the claim that this fosters growth remains speculative.

Indeed, there are plausible arguments that point into the opposite direction. In particular when it comes to developing countries, the availability of tax haven secrecy may help corrupt politicians and administrators to loot the country and to put the booty in secure places. This in turn will lead to a faster depletion of a country's natural resources (Konrad, Olsen and Schöb, 1994) and may increase the return of illegal activities compared to legal activities (Torvik, 2009). Slemrod and Wilson (2009) model tax competitions by introducing costly concealment services from tax havens. They point out that small countries become tax havens endogenously which will erode the tax base on non-haven countries, intensify tax competition and distort optimal tax rates of non-haven countries. Even partially elimination of large tax havens will increase social welfare.

However, there is another possibly beneficial role of tax havens on other countries that has been highlighted in the literature. The initial contribution is by Keen (2001) who argues that in a setting of tax competition, in which developed countries compete for a mobile tax base (i.e. firms' profits), preferential tax schemes and tax havens may cushion the effects of tax competition on tax revenues. HS (2010) put forward a related argument in a somewhat different model. In both cases, the fundamental idea is that the availability of special regimes or tax havens help high-tax countries to differentiate their taxes depending on the nature of the taxed firms, which is usually difficult to achieve. Immobile firms which serve the national markets find it too costly to set up a tax haven affiliate thus can be subjected to a high tax rate. Conversely, internationally mobile firms which would not pay this high tax rate and rather leave the country may take advantage of tax havens and special regimes as instruments to pay a lower tax and stay put. As a result, governments may be able to keep the tax rate on immobile firms high and there is a theoretical possibility that tax revenues of countries are higher than that in a situation in which tax havens and special regimes are absent. ${ }^{5}$

The arguments putting forward depend on the assumption that high-tax countries cannot differentiate their taxes between mobile and immobile activities and therefore some international avoidance schemes are necessary for achieving

\footnotetext{
${ }^{4}$ Another possible channel has been pointed out by Rose and Spiegel (2007). Relying on international cross-country evidence these authors argue that empirically a country's proximity to a tax haven decreases the interest spread between bank lending and borrowing and decreases market concentration among banks. As the authors point out, this may indicate that tax havens increase the competitiveness of nearby banking. It seems also compatible, however, with lower taxes on nearby banks.

${ }^{5}$ For a simple exposition see Dharmapala (2008).
} 
such a differentiation. This is something that may be questioned. For example, the UK patent box regime which is recently under renewed scrutiny provides a lower tax rate to attract mobile capital which actually results in differentiated tax rates within high tax countries. Likewise, developing countries such as China and India have promoted special economic zones which also often offer preferential tax schemes to multinational investors. In addition, the theoretical results are not easily transferable to the question of whether the current crackdown on tax havens is beneficial or not. As emphasized above, tax information exchange has implications for just one feature of tax havens: secrecy. The second characteristic, zero/very low taxation, may still offer the differentiation suggested by HS (2010). As we will argue below, secrecy may matter if the assumption of missing tax rate differentiation by national governments is inappropriate.

\section{Round-tripping and Secrecy}

A striking common feature of the two most populated countries in the world, China and India, is the ownership structure of their inward FDI stock. Figure 1 illustrates this observation for the year 2012. In the case of China, the second largest investor after Hong Kong is the British Virgin Islands, a tax haven jurisdiction with a number of some 30,000 inhabitants. In the case of India, the single largest share of foreign investments comes from Mauritius, a country with a population of 1.3 million that tops the UK and the US by a wide margin. In both cases it is evident that these jurisdictions are mere conduit countries for investments into China and India as domestic savings in these countries are insufficient to finance foreign acquisitions of these magnitudes. A similar qualification applies to the role of Hong Kong for FDI in China.

A somewhat more difficult question is the one about the ultimate investors who use these conduit countries. In both cases it is conceivable that a large part of the investments are not coming from abroad but originating from China and India. Mauritius counts the highest share $(42 \%)$ of FDI inflows to India accumulating from 2000 to 2011 (Department of Industrial Policy and Promotion, country-wise FDI equity inflows), which is viewed to be largely a conduit for round-tripping investments benefiting from a preferential double taxation treaty. In the case of China, the World Bank (2002, p.41) has estimated the fraction of round-tripping in Chinese inward investment at some $25 \%$ after reviewing previous papers and aggregated figures. Indirect empirical evidence for round-tripping investment in China has recently been provided by Fuest and Li (2015). The possible motivation for this round-tripping is preferential taxation of foreign-owned firms compared to national firms, escaping from currency regulations that are applied differentially to foreign and domestic-owned firms. In addition, property rights may be generally better protected for foreign-owned firms and miscellaneous legal and institutional settings could be avoid. As a result, for example, Darius and Williams (1997) have argued that the return of Hong Kong to China has led a large exodus of firms to the British Virgin 
Islands. Finally, routing via Hong Kong may allow Chinese firms to tap into foreign capital markets (Xiao, 2004).

Table 1. Main Investor Countries, China and India (Stocks, 2012)

\begin{tabular}{lrlr}
\hline \multicolumn{2}{c}{ Main FDI investors in China } & \multicolumn{2}{c}{ Main FDI investors in India } \\
\hline 1 Hong Kong, China & 592.2 & 1 Mauritius & 57.7 \\
2 British Virgin Islands & 129.4 & 2 United Kingdom & 35.6 \\
3 Japan & 87.2 & 3 United States & 32.6 \\
4 US & 70.2 & 4 Singapore & 17.7 \\
5 Singapore & 59.2 & 5 Japan & 15.5 \\
6 Taiwan Province of China & 57.0 & 6 Germany & 12.6 \\
7 Korea, Republic of & 52.9 & 7 Switzerland & 11.1 \\
8 Cayman Islands & 25.8 & 8 Netherlands & 10.5 \\
9 Samoa & 19.9 & 9 France & 3.8 \\
10 Germany & 19.8 & 10 Korea, Republic of & 3.1 \\
11 United Kingdom & 17.7 & 11 Cyprus & 2.5 \\
12 Netherlands & 12.8 & 12 Finland & 1.6 \\
13 France & 11.5 & 13 Italy & 1.3 \\
14 Mauritius & 11.5 & 14 United Arab Emirates & 1.2 \\
15 Macao, China & 10.4 & 15 Sweden & 1.1 \\
16 Canada & 8.3 & 16 Hong Kong, China & 0.7 \\
17 Malaysia & 6.0 & 17 Belgium & 0.7 \\
18 Italy & 5.5 & 18 Spain & 0.7 \\
19 Barbados & 3.9 & 19 Denmark & 0.6 \\
20 Thailand & 3.4 & 20 China & 0.6 \\
\hline Total & 1343.6 & Total & 218.1 \\
\hline
\end{tabular}

Note: FDI figures (stocks) are in billion of US dollars. Source: Unctad, Bilateral FDI Statistics 2014, http://unctad.org/en/Pages/DIAE/FDI\%20Statistics/FDI-Statistics-Bilateral.aspx.

To the extent that differential tax treatment between foreign and domestically owned firms is one of the motives for round-tripping investments, the availability of tax havens to obscure true ownership may impede the use of differential taxation. In the past China has made use of measures to provide for such a differentiation, in particular before the tax reform in 2008 that ended a preferential $15 \%$ tax rate for foreign-owned companies and introduced a common $25 \%$ rate for domestic and foreign firms. The official purpose of the 2008 reform was to provide fair competition environment between domestic and foreign corporations, to safeguard tax sovereignty, and to improve China's economic structure and promote development (the Enterprise Income Tax [EIT] Law of the People's Republic of China, 2007; Shu, 2014). However, it has also been argued that the EIT 2007 is to effectively deal with the round-tripping investments of Chinese enterprises listed in Hong Kong and other tax havens, as their income occurring inside China is now taxed at the same rate (Li, 2008). 


\section{Modeling the Influence of Tax Havens on Tax Policy}

In this section, we pick up the fact that some countries are in a position to differentiate their taxes between domestic firms and more mobile international (foreign-owned) firms. Our focus is on analyzing how this influences the welfare implications of tax haven services. To do so we adapt the model by HS (2010). Unlike done there, however, we assume that the government is able to differentiate tax rates on mobile and immobile companies. Both rates are restricted to be chosen between 0 and 1 . As long as the tax rate $t_{m}$ which is applicable for international firms is below the tax rate on national firms $t_{d}$ (a constellation that will be shown to be optimal below), domestic companies have an incentive to hide via round-tripping, which is made possible through the secrecy of tax havens. To model the implications of tax havens and their services for roundtripping investment, suppose that domestic firms will take resort of a tax haven with a probability $p$, where $p$ is assumed to be an increasing function of the number of available tax havens $T H$, i.e. $p(T H)$. For simplicity, firms do not suffer additional costs when they make the decision to a tax haven and pretend to be foreign-owned.

As mentioned above, there are two types of firms in the model. The output of mobile international companies is $F\left(L_{m}, K\right)$, which is a strictly concave, constant returns of scale production function of labor $L_{m}$ and capital $K$. Capital $K$ for foreign-owned companies is obtained with a fixed price $r$ in the world market. It is further assumed that labor is inelastically supplied and flexibly moving between domestic and foreign-owned firms, Both domestic labor $L_{d}$ and multinational labor $L_{m}$ face the same wage rate $w$ and the supply of total labor is normalized to unity. With labor $L_{d}$ and fixed amount of capital $D$ domestic companies produce output $G\left(L_{d}, D\right)$, which is also a strictly concave production function with constant returns. Both mobile and immobile companies maximize their net-of-tax profits while only labor is assumed to be tax deductible.

The objective function for mobile companies is:

$$
\left(1-t_{m}\right)\left[F\left(L_{m}, K\right)-w L_{m}\right]-r K,
$$

Capital and labor demand of mobile firms are derived from the first-order conditions:

$$
\begin{aligned}
F_{L}\left(L_{m}, K\right) & =w, \\
F_{K}\left(L_{m}, K\right) & =\frac{r}{1-t_{m}}=\rho .
\end{aligned}
$$

The availability of tax haven services allows a fraction $p$ of domestic firms to disguise as international firms. Since capital $D$ for domestic firms is fixed, immobile companies maximize their net-of-tax profits by:

$$
\left(1-t_{d}\right)\left[G\left(L_{d}, D\right)-w L_{d}\right](1-p(T H))+\left(1-t_{m}\right)\left[G\left(L_{d}, D\right)-w L_{d}\right] p(T H),
$$


where $G\left(L_{d}, D\right)-w L_{d}=\pi(w)$ is the profits of immobile companies before paying taxes. In our setup, only a fraction $1-p(T H)$ of domestic firms pay corporate income tax $t_{d}$, while the rest are able to disguise as foreign-owned firms and pay a lower tax $t_{m}$. Despite the introduction of $p$ from equation (4), the first-order condition of labor input $\left[G_{L}\left(L_{d}, D\right)=w\right]$ exactly corresponds to HS (2010).

The government collects total tax revenues of

$\left.T=t_{m}\left[\left(F\left(L_{m}, K\right)-w L_{m}\right)+p\left(G\left(L_{d}, D\right)-w L_{d}\right)\right]+t_{d}(1-p)\left[G\left(L_{d}, D\right)-w L_{d}\right)\right]$.

From the zero-profit condition of mobile companies and the market clearing condition of domestic labor, where supply is normalized to unity, we have

$$
\begin{aligned}
F & =w L+\rho K, \\
L_{m}(w, \rho)+L_{d}(w, D) & =1 .
\end{aligned}
$$

The government sets up optimal policies by maximizing social welfare and is restrained to set tax rates between zero and one. Following HS (2010), there are two types of consumers: workers and entrepreneurs, who consume all the productions in the market. Entrepreneurs act as the owners of domestic firms. In addition, the government redistributes tax revenues from entrepreneurs to workers by giving workers all the tax revenues as a lump-sum payment. Therefore, the aggregated consumption of workers $C_{w}$ is: $C_{w}=$ $w+T$, while the aggregated consumption of entrepreneurs $C_{E}$ is given by $\left[\left(1-t_{d}\right)(1-p(T H))+\left(1-t_{m}\right) p(T H)\right] \pi(w)$. It is further supposed that the total consumption $C_{E}$ of entrepreneurs is weighted by a parameter $\beta$ in the social welfare function, $\beta<1$.

It follows that the government objective function is described as a weighted sum of consumptions: $\Omega=C_{w}+\beta C_{E}$. Since markets clear and total production is consumed, i.e., $C_{w}+C_{E}=Y$, the government maximizes social welfare by choosing the optimal tax rates $t_{m}$ and $t_{d}$ from:

$$
\begin{aligned}
\max _{\left\{t_{m}, t_{d}\right\}:}: & \Omega \\
& \text { s.t. }: \rho=\frac{r}{1-t_{m}}, \\
& L_{m}(w, \rho)+L_{d}(w, D)=1 .
\end{aligned}
$$

Since the total consumption $\Omega$ could be written as $Y-(1-\beta) C_{E}=F\left(L_{m}, K\right)-$ $r K+G\left(L_{d}, D\right)-(1-\beta)\left[\left(1-t_{d}\right)(1-p(T H))+\left(1-t_{m}\right) p(T H)\right] \pi(w)$, we obtain the following first-order conditions:

$$
\begin{gathered}
\frac{\partial \Omega}{\partial t_{d}}=(1-\beta)(1-p) \pi(w)>0 \\
\frac{\partial \Omega}{\partial t_{m}}=F_{K} \frac{\partial K}{\partial \rho} \frac{\partial \rho}{\partial t_{m}}-r \frac{\partial K}{\partial \rho} \frac{\partial \rho}{\partial t_{m}}-(1-\beta)(-p) \pi(w) \\
-(1-\beta)\left[\left(1-t_{d}\right)(1-p)+\left(1-t_{m}\right) p\right] \frac{\partial \pi}{\partial w} \frac{\partial w}{\partial \rho} \frac{\partial \rho}{\partial t_{m}} \\
=0
\end{gathered}
$$


From (11), the optimal tax rate for domestic immobile firms is $100 \%$.

A special case is the one without any tax haven: $p(T H)=0$. The first-order conditions can then be simplified as:

$$
\begin{gathered}
\frac{\partial \Omega}{\partial t_{d}}=(1-\beta) \pi(w)>0 \\
\frac{\partial \Omega}{\partial t_{m}}=F_{K} \frac{\partial K}{\partial \rho} \frac{\partial \rho}{\partial t_{m}}-r \frac{\partial K}{\partial \rho} \frac{\partial \rho}{\partial t_{m}}-(1-\beta)\left(1-t_{d}\right) \frac{\partial \pi}{\partial w} \frac{\partial w}{\partial \rho} \frac{\partial \rho}{\partial t_{m}}=0
\end{gathered}
$$

From (14) we obtain $(\rho-r) K_{\rho}=(1-\beta)\left(1-t_{d}\right) \frac{\partial \pi}{\partial w} \frac{\partial w}{\partial \rho} \frac{\partial \rho}{\partial t_{m}}$. From (13), the optimal tax rate for domestic immobile firms will be set to $100 \%$ as well. Consequently, $\rho=r$, which implies a zero tax rate on foreign companies. In other words, when there is no tax haven, the government optimizes social welfare by fully taxing immobile domestic firms, which have to bear the whole tax burden.

The next step is to examine social welfare with respect to the number of tax havens: assume now the government has already optimized tax rates $t_{m}$ and $t_{d}$ such that total welfare is optimized as well: $\Omega^{*}\left(t_{m}^{*}, t_{d}^{*}\right)$. Using the envelop theorem, the change in welfare that follows an increase in the fraction of domestic firms $p$, which can pretend to be international, can be obtained as:

$$
\frac{d \Omega^{*}}{d p}=-(1-\beta)\left(t_{d}^{*}-t_{m}^{*}\right) \pi(w)<0 .
$$

As a result, since by assumption $d p(T H) / d T H>0$, tax havens have a negative impact on social welfare. As indicated by (15), the negative effect derives from the fact that more domestic firms can pretend to be foreign and this leads to a reduction of tax revenue measured by $\left(t_{d}^{*}-t_{m}^{*}\right) \pi(w)$ and evaluated at the differential shadow price $(1-\beta)$ of workers' and entrepreneurs' income.

Intuitively, we would expect that the possibility of some domestic firms to hide in the pool of international firms will not only lead to a welfare loss for the country under consideration. In addition, it is plausible that there is an upward change in the optimal tax rate $t_{m}$, as taxing the respective pool is partly a tax on immobile (but round-tripping) investments. The appendix contains a proof of this intuition based on linear labor and capital demand.

In a generalized setup, the probability $p$ is naturally to be assumed as a function not only of the number of tax havens, but also the difference between tax rates on domestic immobile and multinational mobile firms, denoted as $p\left(T H, t_{d}-t_{m}\right)$. In this case, the welfare function of the government is generalized to be $\Omega^{*}\left(t_{m}^{*}, t_{d}^{*}\right)=F\left(L_{m}, K\right)-r K+G\left(L_{d}, D\right)-(1-\beta)\left[\left(1-t_{d}^{*}\right)\left(1-p\left(T H, t_{d}^{*}-\right.\right.\right.$ $\left.\left.\left.t_{m}^{*}\right)\right)+\left(1-t_{m}^{*}\right) p\left(T H, t_{d}^{*}-t_{m}^{*}\right)\right] \pi(w)$. Based on the envelop theorem, the result of (15) continues to hold and the above mentioned negative impact of tax havens on social welfare prevails. 


\section{Conclusions}

A much cited argument claims that tax haven services may allow high tax countries to differentiate their tax rates between mobile international firms and immobile national firms if such a differentiation is not possible otherwise. The present paper is motivated by (i) the observation that some countries, most notably China, in the past have differentiated their tax rates between domestic and foreign firms and (ii) many countries have difficulties to tell apart national firms from international firms because of a high suspected share of round-tripping investments. Bringing together these two observations in an amended HongSmart model reverses the conclusion that tax havens are good. However, under the enforcement of base erosion and profit shifting (BEPS) conducted by OECD, if tax rates are forced to be equalized on mobile international and immobile national firms, then the remaining non-cooperative tax havens could serve a new role on high tax countries.

\section{Appendix}

From the analysis in section 5, we know that immobile companies that reveal as such will always be taxed fully. Therefore, when tax havens are available, immobile companies will have incentives to shift foreign and pretend to be a multinational company. In order to obtain the optimal tax rate on mobile companies, it is worth examining the first-order conditions of the government objective function with respect to the tax rate on mobile companies $t_{m}$. The following equation is simplified and ordered from the first-order condition (14) in section 5 :

$$
\frac{\partial \Omega}{\partial t_{m}}=(\rho-r) C+(1-\beta) p \pi(w)-(1-\beta) A B=0,
$$

where:

$$
\begin{aligned}
A & =\left(1-t_{d}\right)(1-p)+\left(1-t_{m}\right) p \\
B & =\frac{\partial \pi}{\partial w} \frac{\partial w}{\partial \rho} \frac{\partial \rho}{\partial t_{m}} \\
C & =K_{\rho} \frac{\partial \rho}{\partial t_{m}}
\end{aligned}
$$

Since the optimal tax rate on domestic firms $t_{d}^{*}$ equals $1, A=\left(1-t_{m}\right) p$.

Moreover, according to the capital demand function of mobile companies: $\rho=\frac{r}{1-t_{m}}$. The gross-of-tax user cost of capital $\rho$ changes with the change of tax rate on mobile companies $t_{m}$ accordingly:

$$
\frac{\partial \rho}{\partial t_{m}}=\frac{r}{\left(1-t_{m}\right)^{2}}=\frac{\rho^{2}}{r} .
$$


Plugging A, B, C and the above derivative into equation (16), it could be written as:

$$
(\rho-r) K_{\rho} \frac{\rho^{2}}{r}+(1-\beta) p \pi(w)-(1-\beta) \rho p \frac{\partial \pi}{\partial w} \frac{\partial w}{\partial \rho}=0 .
$$

Since $r$ is defined (HS (2010)) as the fixed rental price for capital in the world market, equation (21) can be considered as a function of $\rho$ and $p$. Taking the total differentiate of equation (21) on both sides one obtains the following:

$$
\begin{aligned}
& {\left[(1-r) K_{\rho} \frac{\rho^{2}}{r}+(\rho-r) K_{\rho} \frac{2 \rho}{r}\right] d \rho+(\rho-r) \frac{\rho^{2}}{r} K_{\rho \rho} d \rho+(1-\beta) \pi(w) d p} \\
& -(1-\beta) \frac{\partial \pi}{\partial w} \frac{\partial w}{\partial \rho} \rho d p+(1-\beta) p \frac{\partial \pi}{\partial w} \frac{\partial w}{\partial \rho} d \rho \\
& -(1-\beta) p \rho \pi_{w \rho} \frac{\partial w}{\partial \rho} d \rho-(1-\beta) p \rho \frac{\partial \pi}{\partial w} w_{\rho \rho} d \rho-(1-\beta) p \frac{\partial \pi}{\partial w} \frac{\partial w}{\partial \rho} d \rho \\
& =0
\end{aligned}
$$

Solving equation (22) gives us $\frac{d \rho}{d p}$ :

$$
\frac{d \rho}{d p}=\frac{(1-\beta) \pi(w)-(1-\beta) \rho \pi_{w} w_{\rho}}{-\left[(1-r) \frac{\rho^{2}}{r}+2(\rho-r) \frac{\rho}{r}\right] K_{\rho}-(\rho-r) \frac{\rho^{2}}{r} K_{\rho \rho}+(1-\beta) p \rho\left(\pi_{w \rho} w_{\rho}+\pi_{w} w_{\rho \rho}\right)}
$$

In order to solve the problem for the optimal tax rate for multinational companies, we need to solve $(1-\beta) \pi(w)$ by using equation (16):

$$
\frac{\partial \Omega}{\partial t_{m}} \frac{1}{p}:-(\rho-r) \frac{C}{p}+\frac{1-\beta}{p} A B=(1-\beta) \pi(w)
$$

By plugging $(1-\beta) \pi(w)$ into equation $(24)$, we obtain:

$$
\frac{d \rho}{d p}=\frac{\frac{-(\rho-r) \rho^{2}}{p} K_{\rho}}{-\left[(1-r) \rho^{2}+2 \rho(\rho-r)\right] K_{\rho}-\hat{A} K_{\rho \rho}+\hat{B} \pi_{w \rho}+\hat{C} w_{\rho \rho}}
$$

Where:

$$
\begin{aligned}
& \hat{A}=(\rho-r) \rho^{2} \\
& \hat{B}=(1-\beta) p \rho r w_{\rho} \\
& \hat{C}=(1-\beta) p \rho r \pi_{w}
\end{aligned}
$$

Equation (25) is positive if demand for capital and labour are linear. In other words, $K_{\rho \rho}, \pi_{w \rho}$ and $w_{\rho \rho}$ are all equal to zero. Under this condition, the grossof-tax user cost of capital $\rho$ for foreign companies is positively correlated with the probability of domestic companies shifting foreign, $p$. Since it is assumed that the probability $p(T H)$ is an increasing function of the number of tax havens 
$T H$, the rent of capital monotonically increases with the number of tax havens as well. Consequently, it proves that once tax rates are differentiated, the more tax havens available, the higher the optimal tax rate will be set on multinational companies. 


\section{References}

- Bilicka, Katarzyna and Clemens Fuest (2014), With which countries do tax havens share information?, International Tax and Public Finance 21(2), 175-197.

- Blonigen, Bruce and Ron Davies (2004), The effects of bilateral tax treaties on U.S. FDI activity, International Tax and Public Finance 11(5), 601-622.

- Blonigen, Bruce, Lindsay Oldensky, and Nicholas Sly (2014), The differential effects of bilateral tax treaties, American Economic Journal. Economic Policy 6(2), 1-18.

- Braun, Julia and Alfons Weichenrieder (2015), Does exchange of information between tax authorities influence multinationals' use of tax havens?, Goethe University Frankfurt, SAFE Working Paper No. 89.

- Darius, Reginald and Oral Williams (1997), Impact of growth in international business companies on the British Virgin Islands economy: Lessons for the ECCB area, Social and Economic Studies 46(2\&3), 169-198.

- Desai, Mihir A., C. Fritz Foley and James R. Hines (2006a), The demand for tax haven operations, Journal of Public Economics 90(3), 513-531.

- Desai, Mihir A., C. Fritz Foley and James R. Hines (2006b), Do tax havens divert economic activity?, Economic Letters 90(2), 219-224.

- Dharmapala, Dhammika (2008), What problems and opportunities are created by tax havens?, Oxford Review of Economic Policy 24(4), 661679 .

- Dharmapala, Dhammika and James R. Hines (2009), Which countries become tax havens?, Journal of Public Economics 93(9), 1058-1068.

- Fuest, Clemens and Li Liu (2015), Does ownership affect the impact of taxes on firm behavior? Evidence from China, CESifo Working Paper No. 5316.

- Gordon, Richard K. (2009), Laundering the proceeds of public sector corruption, Case Western Reserve University, Case Legal Studies Research 09-10.

- Hanlon, Michelle, Edward L. Maydew and Jacob R. Thornock (2015), Taking the long way home: U.S. tax evasion and offshore investments in U.S. equity and debt markets, Journal of Finance 70(1), 257-287.

- Hebous, Shafik (2014), Money at the docks of tax havens: A guide, FinanzArchiv/ Public Finance Analysis 70(3), 458-485. 
- Hebous, Shafik and Vilen Lipatov (2014), A journey from a corruption port to a tax haven, Journal of Comparative Economics 42(3), 739-754.

- Hines, James R. (2010), Treasure islands, Journal of Economic Perspectives 24(4), 103-126.

- Hong, Qing and Michael Smart (2010), In praise of tax havens: International tax planning and foreign direct investment, European Economic Review 54(1), 82-95.

- Johannesen, Niels and Gabriel Zucman (2014), The end of bank secrecy? An evaluation of the G20 tax haven crackdown, American Economic Journal: Economic Policy 6(1), 65-91.

- Karkinsky, Tom and Nadine Riedel (2012), Corporate taxation and the choice of patent location within multinational firms, Journal of International Economics 88(1), 176-185.

- Keen, Michael (2001), Preferential regimes can make tax competition less harmful, National Tax Journal 54(4), 757-762.

- Konrad, Kai A., Trond E. Olsen and Ronnie Schöb (1994), Resource extraction and the threat of possible expropriation: The role of Swiss bank accounts, Journal of Environmental Economics and Management 26(2), 149-162.

- Li, Qun (2008), Tax incentive policies for foreign-invested enterprises in China and their influence on foreign investment, Revenue Law Journal 18(1), 5 .

- OECD (2010), Promoting transparency and exchange of information for tax purposes: A background information brief, OECD.

- OECD (2013), Progress report to the G20 leaders: Global forum update on effectiveness and on-going monitoring, OECD, Paris.

- Rose, Andrew K. and Mark M. Spiegel (2007), Offshore financial centres: Parasites or symbionts?*, The Economic Journal 117(523), 1310-1335.

- Ruf, Martin and Alfons J. Weichenrieder (2012), The taxation of passive foreign investment - Lessons from German experience, Canadian Journal of Economics 45(4), 1504-1528.

- Schindler, Dirk and Guttorm Schjelderup, (2012), Debt shifting and ownership structure, European Economic Review 56(4), 635-647.

- Schjelderup, Guttorm (2011), Secrecy jurisdictions, Working Paper, Norwegian School of Economics and Business Administration. 
- Sharman, Jason C. (2010), Shopping for anonymous shell companies: An audit study of anonymity and crime in the international financial system, Journal of Economic Perspectives 24(4), 127-140.

- Slemrod, Joel and John D. Wilson (2009), Tax competition with parasitic tax havens, Journal of Public Economics 93(11), 1261-1270.

- Shu, Xiaolin (2014), Achievements and problems of China's tax reforms, http://guoqing.china.com.cn/2014-01/13/content_31176059_2.htm.

- Torvik, Ragnar (2009), Why are tax havens more harmful to developing countries than to other countries?, Memorandum written for the Commission to the Government Commission on Tax Havens, Department of Economics, NTNU.

- Weichenrieder, Alfons J. (2009), Profit shifting in the EU: Evidence from Germany, International Tax and Public Finance 16(3), 281-297.

- World Bank (2002), Global development finance: Financing the poorest countries, Washington.

- Xiao, Geng (2004), People's Republic of China's round-tripping FDI: Scale, causes and implications, ADB Institute Discussion Paper Paper No. 7. 


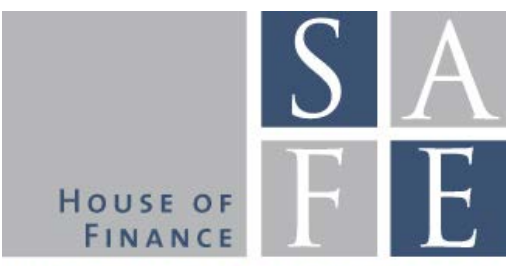

WORKING PAPER SERIES

\section{Recent Issues}

No. 110 Dirk Krueger, Alexander Ludwig

No. 109 Tobias Tröger

No. 108 Sascha Baghestanian, Paul Gortner, Baptiste Massenot

No. 107 Daniel Powell, Marc Steffen Rapp

No. 106 Baptiste Massenot, Stéphane Straub

No. 105

No. 104

No. 103

Massimiliano Caporin, Loriana

Pelizzon, Francesco Ravazzolo,

Roberto Rigobon

No. 102 Iñaki Aldasoro, Iván Alves

No. 101 Marcel Grupp

No. $100 \quad$ Marcel Grupp

No.99 Marcel Grupp, Christian Rauch, Marc Umber, Uwe Walz

No.98 Tobias Niedrig, Helmut Gründl
On the Optimal Provision of Social Insurance

Regulatory Influence on Market Conditions in the Banking Union

Compensation Schemes, Liquidity Provision, and Asset Prices: An Experimental Analysis

Non-Mandatory Say on Pay Votes and AGM Participation: Evidence from Germany

Informal Sector and Economic Development: The Credit Supply Channel

A Decentralization Theorem of Taxation

Predictably Irrational: Gambling for Resurrection in Experimental Asset Markets?

Measuring Sovereign Contagion in Europe

Multiplex interbank networks and systemic importance: An application to European data

On the Impact of Leveraged Buyouts on Bank Systemic Risk

Taking the Lead: When Non-Banks Arrange Syndicated Loans

The Influence of Leveraged Buyouts on Target Firms' Competitors

The Effects of Contingent Convertible (CoCo) Bonds on Insurers' Capital Requirements Under Solvency II 